\title{
Multiple myeloma: when radiography suggests diagnosis
}

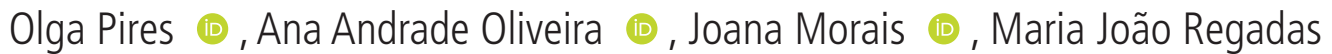

Internal Medicine, Hospital de Braga, Braga, Portugal

Correspondence to Dr Olga Pires; olgappires@gmail.com

Accepted 29 March 2021

\section{DESCRIPTION}

Multiple myeloma (MM) can present courses with lytic bone destruction caused by increased osteoclastic activity. These images are of a 64 -year-old woman who presented to health services with neck and shoulder pain, anorexia, asthenia and weight loss, with months of evolution and multiple recurrences. She denied other symptoms. The radiological study showed lytic lesions of the cranial cap, tibia, fibula, radius, ulna and cervical region, suggestive of MM (figure 1). The diagnosis was confirmed by protein electrophoresis and light urinary chain dosage. The obtained radiography images are of particular interest given the lesser frequency of use of radiography as a complementary diagnostic method to CT examination, despite their value in guiding diagnosis.

$\mathrm{MM}$ is a malignancy of plasma cells that can cause the failure of the bone marrow, leading to anaemia, immune paresis with resultant infection, bone pain and fractures, high calcium levels and renal failure. ${ }^{1} \mathrm{MM}$ is the second most common haematological malignancy, representing $10 \%-15 \%$ of all new diagnoses. ${ }^{2}$ The disease is more common in men, and the median survival is currently $4-8$ years, partly depending on age at presentation. ${ }^{1} \mathrm{MM}$ often presents with a high symptomatic burden, most commonly with fatigue and bone pain. ${ }^{3}$ The ability of haematopoietic stem cells to produce new blood cells is diminished, as the bone marrow becomes filled with malignant plasma cells, leading to anaemia and in some cases, but less commonly, thrombocytopenia and neutropaenia. ${ }^{4}$ The hallmark of MM is a severe destructive bone disease. Lytic skeletal lesions are also detected in approximately $80 \%$ of patients. ${ }^{4}$ The primary cause of the bone

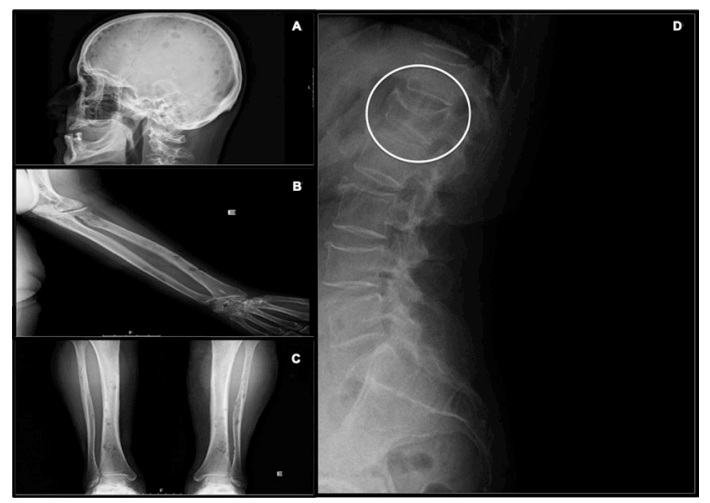

Figure 1 Lytic lesions observed in X-ray image of skull bone (A), left arm (B), lower limbs (C) and vertebral column with vertebra flattening as it is shown inside the circle (D). disease is increased osteoclastic activity, which occurs close to active myeloma cells. Other common findings are hypercalcaemia, impairment of renal function and infection. ${ }^{5}$

This image is of clinical interest as it evidences that a basic and quick approach bone X-ray examination allows for a relevant diagnosis. It is important to note that although $80 \%$ of patients with MM have lytic lesions, contrary to what was seen in this patient, many of these patients may be asymptomatic due to the bone lesions. If this were the case, and these images or a subset of them were obtained for another reason, the pattern present in the images would still point to a probable diagnosis of $\mathrm{MM}$, which should be confirmed or ruled out by blood tests.

\section{Learning points}

For further guiding the diagnosis, radiography is a relevant complementary diagnostic test to perform as a first approach on patients with reports of bone pain and suspicion of multiple myeloma.

- As radiography is a commonly requested test, it is important to be aware of certain changes that may indicate an additional diagnosis, even if it may be a finding in some circumstances.

Contributors OP: Conception and design of the article, acquisition of the data, drafting the article and revising it critically for important intellectual content, and final approval of the article. AAO, JM and MJR: Revision for important intellectual content and final approval of the article.

Funding The authors have not declared a specific grant for this research from any funding agency in the public, commercial or not-for-profit sectors.

Competing interests None declared.

Patient consent for publication Obtained.

Provenance and peer review Not commissioned; externally peer-reviewed.

\section{ORCID iDs}

Olga Pires http://orcid.org/0000-0003-0618-9820

Ana Andrade Oliveira http://orcid.org/0000-0002-8603-8020

Joana Morais http://orcid.org/0000-0002-6588-9010

\section{REFERENCES}

1 Bird SA, Boyd K. Multiple myeloma: an overview of management. Palliat Care Soc Pract 2019:13:117822421986823:1-13.

2 Smith D, Yong K. Multiple myeloma. BMJ 2013;346:f3863.

3 Rajkumar SV, Kumar S. Multiple myeloma: diagnosis and treatment. Mayo Clin Proc 2016;91:101-19.

4 Anderson KC, Carrasco RD. Pathogenesis of myeloma. Annu Rev Pathol 2011;6:249-74.

5 Kristinsson SY, Minter AR, Korde N, et al. Bone disease in multiple myeloma and precursor disease: novel diagnostic approaches and implications on clinical management. Expert Rev Mol Diagn 2011;11:593-603. 
Images in...

Copyright 2021 BMJ Publishing Group. All rights reserved. For permission to reuse any of this content visit https://www.bmj.com/company/products-services/rights-and-licensing/permissions/

BMJ Case Report Fellows may re-use this article for personal use and teaching without any further permission.

Become a Fellow of BMJ Case Reports today and you can:

- Submit as many cases as you like

- Enjoy fast sympathetic peer review and rapid publication of accepted articles

Access all the published articles

Re-use any of the published material for personal use and teaching without further permission

Customer Service

If you have any further queries about your subscription, please contact our customer services team on +44 (0) 2071111105 or via email at support@bmj.com.

Visit casereports.bmj.com for more articles like this and to become a Fellow 